\title{
РІВЕНЬ ДУХОВНОГО РОЗВИТКУ СТУДЕНТІВ ГУМАНІТАРНОГО УНІВЕРСИТЕТУ ТА ЙОГО ЗВ'ЯЗОК ІЗ САМООЦІНКОЮ ЗДОРОВ'Я
}

\author{
Савченко Валентин ${ }^{1 A C}$, Буряк Ольга ${ }^{1 B}$, Комочька Оксана ${ }^{I D}$, Погребняк Юлія ${ }^{1 B}$, Якимчук Олег ${ }^{1 B}$ \\ ${ }^{1}$ Київський університет імені Бориса Грінченка,
}

Київ, Україна

\begin{abstract}
Внесок автора: А - дизайн дослідження; В - збір даних; C - статистичний аналіз;
$\mathrm{D}$ - підготовка рукопису.
\end{abstract}

\begin{abstract}
Анотація
Мета - оцінити рівень духовного розвитку студентів гуманітарного університету та встановити його зв'язок із самооцінкою здоров'я.

Методи. 64 студенти Київського університету імені Бориса Грінченка. Юнаків було 29 (45,3 \%),

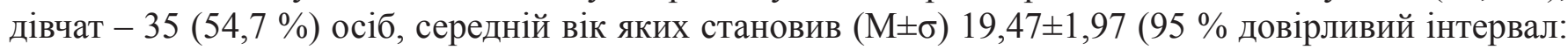
18,98-19,96) років. Рівень духовного розвитку студентів встановлювали шляхом опитування, використовуючи спеціальний опитувальник (Гончаренко М.С. і співавт., 2009), стан здоров'я - шляхом самооцінки здоров'я за опитувальником В.П. Войтенка (1991).

Результати. Аналіз духовного розвитку студентів гуманітарного університету показав наявність високого рівня у 46,9 \% (30/64), середнього рівня - у 28,1 \% (18/64), низького рівня - у 17,2 \% (11/64), дуже низького рівня - у 1,6 \% (1/64) осіб. Рівень духовності недиференційовано у 6,3 \% (4/64) студентів. Здоров'я опитуваних, за їхньою самооцінкою, було незадовільним за самопочуттям у 40,6 \% (26/64), задовільним - також у 40,6 \% (26/64), поганим - у 12,5 \% (8/64) та добрим - лише у 6,2 \% (4/64) студентів. При дослідженні зв'язку духовного розвитку студентів із самооцінкою здоров'я такого не виявлено: залежність розподілу висновків про духовний розвиток студентів від розподілу висновків про стан їхнього самопочуття була статистично незначущою $\left(\chi^{2}=6,12, \mathrm{p}=0,9100\right)$.

Висновки. У більшості студентів гуманітарного університету $(53,1 \% ; 34 / 64)$ виявлено незадовільний та поганий стан здоров'я за оцінкою самопочуття (за В.П. Войтенком). Рівень духовного розвитку обстежених студентів найчастіше був високим (46,9%; 30/64), проте у 18,8 \% (12/64) студентів він був низьким і дуже низьким. Зв'язку рівня духовного розвитку з рівнем самооцінки здоров'я студентів не встановлено.
\end{abstract}

Ключові слова: студент, духовний розвиток, самооцінка здоров'я, опитувальник В.П. Войтенка.

\section{Вступ}

Студентська молодь $є$ соціальним прошарком населення, який визначає майбутнє країни як резерв іï трудових ресурсів. Саме тому стан здоров’я цієї групи людей є важливим, оскільки вказує на ії готовність до виконання соціальних і трудових функцій. Сьогодення характеризується невтішним станом здоров'я молоді в Україні. Про це свідчать численні наукові публікації. За результатами соціологічного дослідження в межах міжнародного проекту «Здоров'я та поведінкові орієнтації учнівської молоді» (“Health behaviour school-aged children"), виконаного в
Україні в 2011 році, методом опитування встановлено, що 30 \% респондентів-підлітків оцінюють власне здоров'я як «посереднє» або «погане», і ця кількість з віком зростає, тобто суб'єктивні оцінки самопочуття погіршуються [1].

Король С.А. (2014) вказує, що рівень соматичного здоров'я студентів 1-го курсу переважно знаходиться на низькому та нижче середнього рівнях (78,8 \% юнаків та $81,8 \%$ дівчат), а спеціальну медичну групу або звільнених від занять 3 фізичного виховання складають від $11,7 \%$ до $22,5 \%$ студентів [9]. Боєва А.В., Лещенко Я.А. (2009) за результатами комплексної експрес-оцінки фізич- 
ного (соматичного) здоров'я виявили низький i нижче середнього рівень здоров'я у 12,0 і 11,1\% студентів відповідно [2]. Іванова А.С.. Ковальчук Н.М. (2011) навели дані, що експрес-оцінкою соматичного здоров'я за методикою Г. Апанасенка серед студентів 62,4 \% мають низький рівень здоров'я, 24,7 \% - «нижчий від середнього», 12,9 \% - «середній» [8]. На це вказують і Добростан О.В, Плиска О.І. (2012), які у студенток першого курсу виявили низький рівень соматичного здоров'я та напруження механізмів адаптації [4]. Проведені дослідження інших авторів також показали, що рівень соматичного здоров'я студентів за всіма ознаками $є$ незадовільний і протягом навчання у вищому навчальному закладі погіршується [7, 10, 12, 13, 16, 20 та ін.]. Вказані зміни соматичного здоров'я у студентів обумовлені наявністю хронічної патології з боку внутрішніх органів майже в $66 \%$ обстежених [18].

Наведені дані про стан здоров'я студентів стосувалися їхнього соматичного (фізичного) здоров'я. Відомо, що здоров'я людини є багатокомпонентним явищем [3]. Деякі дослідники не менше значення в описанні здоров'я людини приділяють духовному здоров'ю $[14,15,17]$. Значно менше наукових досліджень присвячено вивченню стану духовного здоров'я студентів. За останні 10 років в україно- та російськомовній науковій літературі (електронні бази даних Національної бібліотеки України імені В.I. Вернадського та Наукової електронної бібліотеки «еLIBRARY.RU») знайдені одиничні праці за цією темою.

Землянская А.Ю., Губина Т.А. (2013) навели дані опитування студентів 2-го курсу медичного університету про вплив здоров'я на сфери життєдіяльності сучасної людини. В 53 \% випадків студенти вважали, що здоров'я впливає, головним чином, на кар'єру і вибір професії, а також на можливість самореалізації, в 27 \% випадків - на сім'ю і міжособистісні відносини, в $18 \%$ випадків - на душевний стан особистості і його внутрішній світ [21]. Дослідники Голубева Г.Н., Голубев А.И. (2018) за результатами опитування встановили перевагу в студентів матеріальних інтересів (61,9\%) над духовними $(38,1 \%)$, а «духовне виснаження» було виявлено у $60 \%$ опитаних [5]. Деякі дослідники вказують про необхідність приділяти увагу духовному здоров'ю студентів, оскільки це може допомогти збереженню та зміцненню їхнього загального здоров'я [11].
Мета дослідження - оцінити рівень духовного розвитку студентів гуманітарного університету та встановити його зв'язок 3 самооцінкою здоров'я.

\section{Методи}

Обстежено 64 студенти, які навчаються в гуманітарному університеті (Київський університет імені Бориса Грінченка). Юнаків було 29 (45,3\%), дівчат - 35 (54,7 \%) осіб. Середній вік

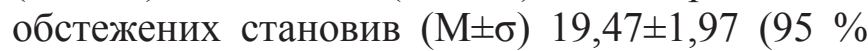
довірливий інтервал: $18,98-19,96)$ років. Для встановлення рівня духовного розвитку студентів використаний опитувальник з навчального посібника Гончаренко М.С. і співавт., 2009 [6, c.41-42]. Цей опитувальник передбачає вибір респондентом любої кількості із 13 тверджень у відповідь на фразу «На мою думку, духовність ųе:». Такими твердженнями (відповідями) були:

a) релігійність;

б) спрямованість людини до високої мети, ідеалів гармонії, що проявляється у внутрішньому світі особистості;

в) моральність;

г) розвиненість інтелектуальних здібностей;

д) емоційні потреби;

е) прагнення оволодіти загальнолюдськими цінностями;

ж) вигадане, неіснуюче поняття;

3) віра в Бога як вищий Розум, любов і справедливість;

i) добре ставлення до всього оточуючого світу;

к) культура мислення, діянь, емоцій, стосунків і харчування;

л) самопізнання і самовдосконалення;

м) те, що мені зовсім не потрібне;

н) ті речі, що мене не обходять.

За авторами цього опитувальника, наявність пунктів б), в), е), з), і), к), л) визначає високий рівень, наявність пунктів а), г), д) - середній рівень, наявність пунктів ж), м), н) - низький рівень духовності. Для більш точного трактування одержаних результатів опитування з залученням арифметичних методів, ми модифікували оцінку цього опитувальника. Нами визначалися чотири рівні духовного розвитку людини:

- високий рівень: наявність пунктів б), е), л);

- середній рівень: наявність пунктів в), з), i), к);

- низький рівень: наявність пунктів а), г), д);

- дуже низький рівень: наявність пунктів ж), м), н). 
Кожному позначеному респондентом відповіді-твердженню присвоювався 1 бал. Для визначення вказаних рівнів духовного розвитку вираховувалися 4 коефіцієнти:

- д для високого рівню: сума балів за пунктами б), е), л) розділити на 3;

- для середнього рівню: сума балів за пунктами в), 3), и), к) розділити на 4;

- для низького рівню: сума балів за пунктами а), г), д) розділити на 3;

- для дуже низького рівню: сума балів за пунктами ж), м), н) розділити на 3;

Далі порівнювалися вирахувані чотири коефіцієнти. Переважаючим рівнем духовності вважався той, який мав найбільше значення коефіцієнта. Якщо були вирахувані однакові значення за декількома коефіцієнтами, то рівень духовного розвитку вважався недиференційованим.

Для самооцінки здоров'я використаний опитувальник В.П. Войтенка (1991) [19], який передбачає надання відповідей на 28 питань. Далі вираховується сума балів (чим більша сума балів, тим гірше самопочуття) та дається висновок про самопочуття обстеженого:

- 0 балів - добре самопочуття;

- 1-5 балів - задовільне самопочуття;

- 6-10- незадовільне самопочуття;

- $\quad$ 11-20 - погане самопочуття;

- більше 20 - дуже погане самопочуття.

Статистичний опис вибірки здійснили методами оцінки варіаційних рядів. Визначали середне арифметичне (М), середнє квадратич- не відхилення (б) та 95 \% довірливий інтервал (95\% ДІ). Зв'язок між рівнем духовного розвитку і самооцінкою здоров'я здійснено шляхом обчислення критерію $\chi^{2}$. Обробка даних дослідження виконана за допомогою програмного продукту IBM SPSS Modeler 18.2.

\section{Результати та обговорення}

Аналіз рівня духовного розвитку студентів гуманітарного університету показав, що респонденти найчастіше обирали 4 відповіді - 25,0 \% (16/64), потім 3 відповіді - 17,2 \% (11/64) та 2 відповіді - 15,6 \% (10/64) на питання опитувальника.

У табл. 1 наведено розподіл кількості тверджень про духовність, які обстежені студенти вибрали у відповідь на питання «На мою думку, духовність це:». 3 цієї таблиці можна зробити висновок, що обстежені студенти у 64,1 \% (41/64) випадках вважали, що духовність - це спрямованість людини до високої мети, ідеалів гармонії, що проявляється у внутрішньому світі особистості, у 56,3 \% (36/64) випадках - культура мислення, діянь, емоцій, стосунків і харчування, у 54,7 \% (35/64) випадках - самопізнання та самовдосконалення, у 42,2 \% (27/64) випадках добре ставлення до всього оточуючого світу, у 35,9 \% (23/64) випадках - емоційні потреби. 3 наведених п'яти тверджень про духовність два $\epsilon$ ознаками високого рівня, два - ознаками середнього рівня, а одне - ознакою низького рівня духовного розвитку.

Таблиия 1

Розподіл кількості вибраних студентами гуманітарного університету тверджень про духовність у відповідь на питання «На мою думку, духовність це:» (n-64)

\begin{tabular}{|l|c|c|c|}
\hline \multicolumn{1}{|c|}{ Твердження про духовність } & $\begin{array}{c}\text { Рівень духовного } \\
\text { розвитку }\end{array}$ & Абс. & \% \\
\hline $\begin{array}{l}\text { Спрямованість людини до високої мети, ідеалів гармонії, що } \\
\text { проявляється у внутрішньому світі особистості }\end{array}$ & Високий & 41 & 64,1 \\
\hline Культура мислення, діянь, емоцій, стосунків і харчування & Середній & 36 & 56,3 \\
\hline Самопізнання та самовдосконалення & Високий & 35 & 54,7 \\
\hline Добре ставлення до всього оточуючого світу & Середній & 27 & 42,2 \\
\hline Емоційні потреби & Низький & 23 & 35,9 \\
\hline Прагнення оволодіти загальнолюдськими цінностями & Високий & 19 & 29,7 \\
\hline Релігійність & Низький & 17 & 26,6 \\
\hline Розвиненість інтелектуальних здібностей & Низький & 16 & 25,0 \\
\hline Віра в Бога як вищий Розум, любов і справедливість & Середній & 15 & 23,4 \\
\hline Моральність & Середній & 9 & 14,1 \\
\hline Ті речі, що мене не обходять & Дуже низький & 6 & 9,4 \\
\hline Те, що мені зовсім не потрібне & Дуже низький & 2 & 3,1 \\
\hline Вигадане, неіснуюче поняття & Дуже низький & 1 & 1,6 \\
\hline
\end{tabular}


Результати розподілу висновків про духовний розвиток студентів гуманітарного університету надано на рис. 1. На цьому рисунку видно, що високий рівень духовного розвитку встановлено в 46,9 \% випадків (30 студентів), середній рівень - в 28,1 \% випадків (18 студентів), низький рівень - в 17,2 \% випадків (11 студентів), дуже низький рівень - в 1,6 \% випадків (1 студент). Рівень духовності недиференційовано в $6,3 \%$ випадків (4 студенти).

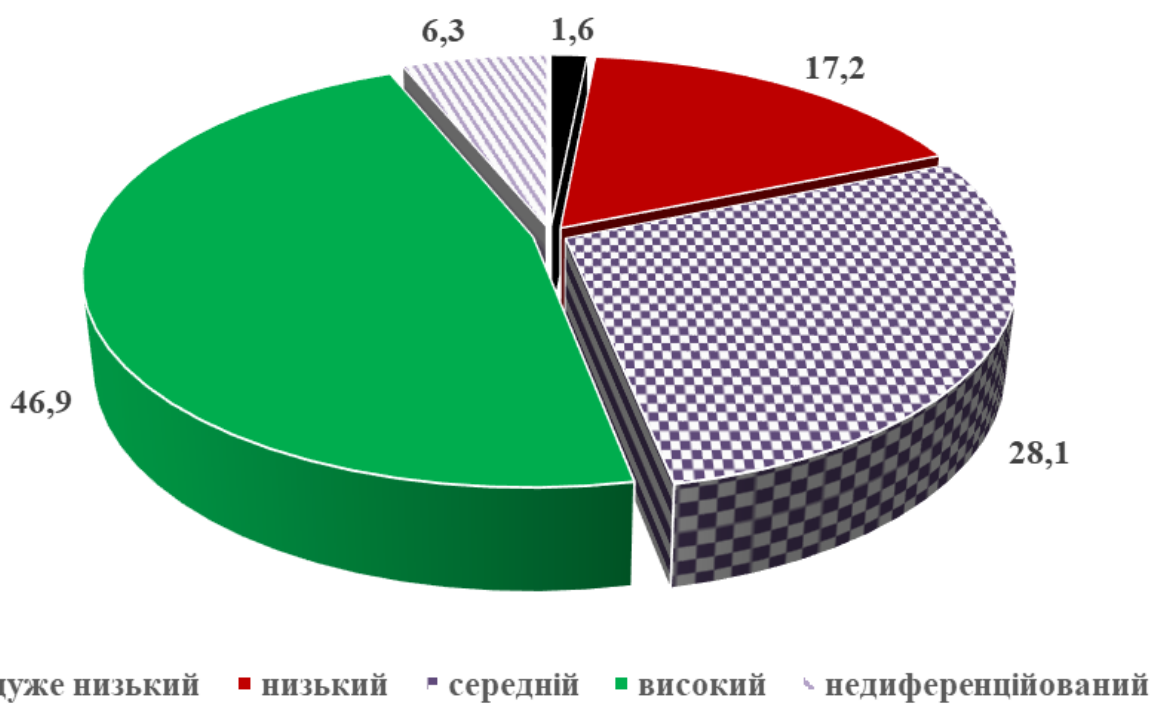

Рис. 1. Розподіл висновків про духовний розвиток студентів гуманітарного університету (\%)

Аналіз здоров'я студентів за їхньою самооцінкою показав наявність незадовільного самопочуття в 40,6 \% випадків (26 студентів), задовільного самопочуття - також в 40,6 \% випадків (26 студентів), поганого самопочуття - в 12,5\% випадків (8 студентів) та доброго самопочуття - лише в 6,2 \% випадків (4 студенти), що продемонстровано на рис. 2. Отже, у більшості обстежених студентів $(53,1 \% ; 34 / 64)$ виявлено незадовільний та поганий стан здоров'я.

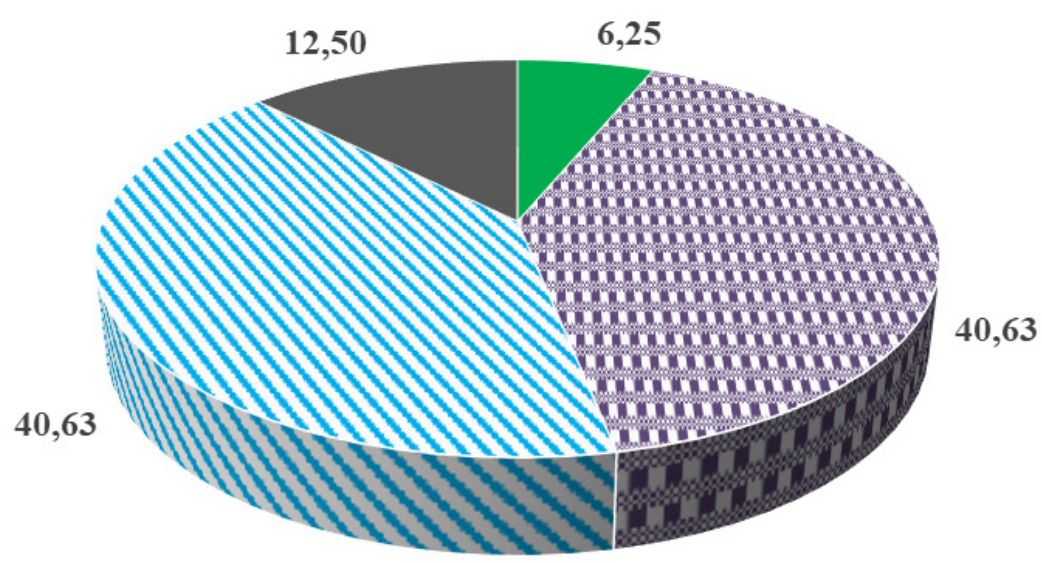

- добре самопочуття
、 незадовільне самопочуття
ข задовільне самопочуття

- погане самопочуття

Рис. 2. Розподіл висновків про стан здоров'я студентів за їхньою самооцінкою, (\%)

У підсумку нами визначено зв'язок духовного розвитку студентів з самооцінкою здоров'я шляхом встановлення залежності розподілу висновків про духовний розвиток студентів від розподілу висновків про стан їхнього самопочуття. Такої залежності не встановлено, оскільки значення критерію $\chi^{2}$ Пірсона становило 6,12, що було статистично незначущим ( $\mathrm{p}=0,9100)$. 
Одержані нами результати підтверджують і доповнюють існуючі уявлення про стан соматичного (фізичного) здоров'я. Як і в інших авторів, які визначали стан соматичного здоров'я переважно за експрес-методикою Г. Апанасенка $[1,2,4,8,9]$, так і у нас, у студентів встановлено (за оцінкою самопочуття з використанням опитувальника В.П. Войтенка) незадовільний та поганий стан $(53,1 \%$; 34/64).

Стан духовності (духовного здоров'я) студентів за останні 10 років у пострадянських країнах майже не вивчався. Дослідники Голубева Г.Н., Голубев А.И. в 2018 році вказали на наявність «духовного виснаження» у $60 \%$ студентів [5]. У нашому випадку благополучний (високий) рівень духовного розвитку студентів гуманітарного університету становив 46,9 \% (30/64). Ці розбіжності можуть бути пов'язані з різним підходом до оцінки стану духовності студентів.

\section{Висновки}

1. У більшості студентів гуманітарного університету $(53,1 \%$; 34/64) виявлено незадовільний та поганий стан здоров'я за оцінкою самопочуття 3 використанням опитувальника В.П. Войтенка.

2. У студентів гуманітарного університету за опитуванням високий рівень духовного розвитку виявляється в 46,9 \% (30/64), середній рівень - в 28,1 \% (18/64), низький рівень в 17,2 \% (11/64), дуже низький рівень - у 1,6 \% (1/64), недиференційований - в 6,3\% (4/64) випадків. Зв'язку рівня духовного розвитку студентів з рівнем самооцінки їхнього здоров'я не встановлено.

\section{Конфлікт інтересів}

Автори заявляють про відсутність конфлікту інтересів.

\section{References}

1. Balakirieva OM, Bondar TV, Artiukh OR ta in. Stan ta chynnyky zdorov'ia ukrains'kykh pidlitkiv : monohrafiia. Kyiv: YuNISEF, Ukr. in-t sots. doslidzh. im. O. Yaremenka. Kyiv: "K.I.S.”, 2011. (In Ukrainian)

Балакірєва ОМ, Бондар ТВ, Артюх ОР та ін. Стан та чинники здоров'я українських підлітків : монографія. Київ: ЮНІСЕФ, Укр. ін-т соц. дослідж. ім. О. Яременка. Київ: “К.І.С.”, 2011.

2. Boyeva AV, Leshchenko YaA. Character of physical development and functional organism abilities in students. Sibirskiy meditsinskiy zhurnal. 2009;5:97-100. (In Russian)

Боева AВ, Лещенко ЯА. Характеристика физического развития и функциональных возможностей организма студентов. Сибирский медицинский журнал. 2009;5:97-100.

3. Constitution of the World Health Organization. New York, 1946 [Internet]. 2006 [cited 2019 May 15] / Available from: http://www.who.int/governance/ eb/who_constitution_ru.pdf. (In Russian)

Устав (Конституция) Всемирной организации здравоохранения. Нью-Йорк, 1946 [Интернет]. 2006 [цитировано 2019 Май 15]. Доступно на: http://www.who.int/governance/eb/who_ constitution_ru.pdf.

4. Dobrostan OV, Plyska OI. Otsinka rivnia somatychnoho zdorov'ia ta pokaznykiv funktsional'noho stanu studentok pershoho kursu instytutu pryrodnycho-heohrafichnoi osvity ta ekolohii NPU im. M. P. Drahomanova. Nauka i osvita. 2012;4:58-60. (In Ukrainian)

Добростан OB, Плиска ОI. Оцінка рівня соматичного здоров'я та показників функціонального стану студенток першого курсу інституту природничо-географічної освіти та екології НПУ ім. М. П. Драгоманова. Наука і освіта. 2012;4:58-60.

5. Golubeva GN, Golubev AI. Ignificance of various factors and detailed health assessment of university students. Nauka i sport: sovremennye tendentsii. 2018;21(4): 96-101. (In Russian)

Голубева ГН, Голубев АИ. Значимость различных факторов и детализированная оценка здоровья у студентов ВУЗа. Наука и спорт: современные тенденции. 2018;21(4): 96-101.

6. Goncharenko MS, Karachins'ka ET, Novikova VE. Diagnostic approaches to determination of the state of spiritual and moral health of the individual: a manual for practical classes. Kharkiv: V.N. Karazin Kharkiv National University; 2009. p. 41-42. (In Ukrainian)

Гончаренко МC, Карачинська ЕТ, Новікова ВС, укладачі. Діагностичні підходи до визначення стану духовного і морального здоров'я особистості: Навчальний посібник для проведення практичних занять. Харків: Харківський національний університет ім. В.Н. Каразіна; 2009. с.41-42. 
7. Goncharenko MS, Pasynok VG, Novikova VE, Martinenko IG, Samoilova NV. Estimation of condition of somatic and mental health of students of higher educational institutions at adaptation to educational process. Педагогіка, психологія та мед.-біол. пробл. фіз. виховання і спорту. 2006;3:12-15. (In Ukrainian)

Гончаренко МС, Пасинок ВГ, Новікова ВЕ, Мартиненко IГ, Самойлова НВ. Оцінка стану соматичного та психічного здоров'я студентів вищих учбових закладів при адаптації до учбового процесу. Педагогіка, психологія та мед.-біол. пробл. фіз. виховання і спорту. 2006;3:12-15.

8. Ivanova A, Kovalchuk N. The Initial levels of the Health State and Physical Fitness of the First Year Students of Ijitsk National Technical University Certain Specialities. Fizychne vykhovannia, sport i kul'tura zdorov'ia u suchasnomu suspil'stvi. 2011;2:57-59. (In Ukrainian)

Іванова АС. Ковальчук НМ. Вихідні рівні стану здоров'я та фізичної підготовленості студентів 1 курсу окремих спеціальностей Луцького національного технічного університету. Фізичне виховання, спорт і культура здоров'я у сучасному суспільстві. 2011;2: 57-59.

9. Korol SA. Assessment of physical health and physical fitness of students of technical specialties of I course. Pedagogics, psychology, medical-biological problems of physical training and sports. 2014;11:23-29. doi:10.15561/18189172.2014.1105 (In Ukrainian)

Король СА. Оцінка стану соматичного здоров'я та фізичної підготовленості студентів і курсу технічних спеціальностей. Педагогіка, психологія та медико-біологічні проблеми фізичного виховання і спорту. 2014;11:23-29. doi:10.15561/18189172.2014.1105

10. Matveev SS. Assessment of the level of health and physical development of students in the dynamics of the four years of study at the university. The Journal of scientific articles "Health and Education Millennium”. 2017;19(10):226-228. (In Russian)

Матвеев СС. Оценка уровня здоровья и физического развития студентов в динамике четырех лет обучения в ВУЗе. The Journal of scientific articles "Health and Education Millennium". 2017;19(10):226-228.

11. Meshko HM. Shliakhy harmonizatsii osobystosti maybutn'oho vchytelia $\mathrm{v}$ systemi pidhotovky do zberezhennia $\mathrm{i}$ zmitsnennia profesiynoho zdorov'ia. Pedahohika vyshchoi ta seredn'oi shkoly. 2012;36:139-146. (In Ukrainian)
Мешко ГМ. Шляхи гармонізації особистості майбутнього вчителя в системі підготовки до збереження i зміцнення професійного здоров'я. Педагогіка вищої та середньої школи. 2012;36:139-146.

12. Mikhaliuk EL, Cherepok AA, Bachuk IN. Vliianie obraza zhizni i zaniatiy po fizicheskomu vospitaniiu na uroven' somaticheskogo zdorov'ia studentov ZGMU. Patolohiia. 2009;2:99-101. (In Russian)

Михалюк ЕЛ, Черепок АА, Бачук ИН. Влияние образа жизни и занятий по физическому воспитанию на уровень соматического здоровья студентов ЗГМУ. Патологія. 2009;2:99-101.

13. Plastunov BA,. Kovaliv MO. Functional condition of cardiovascular system of first-year students of higher educational esteblishments and factors that shape it (reference review). Bukovyns'kyy medychnyy visnyk. 2015;1(73):237-245. (In Ukrainian)

Пластунов БА, Ковалів МО. Функціональний стан серцево-судинної системи першокурсників вищих навчальних закладів і чинники що його формують (огляд літератури). Буковинський медичний вісник. 2015;1(73):237-245.

14. Savchenko VM. The state of spiritual health in patients with people, Crimeans. Reabilitatsiini ta fizkul'turno-rekreatsiini aspekti rozvitku lyudini (Rehabilitation \& recreation). 2017;2:73-78. (In Russian)

Савченко ВМ. Состояние духовного здоровья у больных людей, жителей Крыма. Реабілітаційні та фізкультурно-рекреаційні аспекти розвитку людини (Rehabilitation \& recreation). 2017; 2:73-8.

15. Savchenko V, Buriak O, Kharchenko H, Polkovenko $\mathrm{O}$, Omeri I, Yatsenko S. The spiritual health state of the ill and its connection to the medical conclusions on somatic health at the health resort. Sport Science and Human Health. 2019;1:109-120. (In Ukrainian)

Савченко В, Буряк О, Харченко Г, Полковенко O, Омері I, Яценко С. Стан духовного здоров'я хворих людей та його зв'язок 3 медичними висновками про соматичне здоров'я на курорті. Спортивна наука та здоров'я людини. 2019;1:109-120.

16. Savchuk S. The Analysis of the Somatic Health Status of Students. Fizychne vykhovannia, sport i kul'tura zdorov'ia u suchasnomu suspil'stvi. 2011;3:79-82. (In Ukrainian)

Савчук СА. Аналіз стану соматичного здоров'я студентів вищого технічного на- 
вчального закладу. Фізичне виховання, спорт і культура здоров'я у сучасному суспільстві. 2011;3:79-82.

17. Sviatitel' Luka (Voyno-Yasenetsky). Dukh, dusha i telo [Spirit, soul and body]. Kiev; 2002. p. 144-172. (In Russian)

Святитель Лука (Войно-Ясенецкий). Дух, душа и тело. Киев, 2002. с.144-172.

18. Vanevskaya EA, Ghegalina NM. Social and medical st udy of first year st udents of Dental faculty. Terapevticheskaia stomatologiia. 2012;6:22-24. (In Russian)

Ваневская ЕА, Жегалина НМ. Изучение медикосоциального статуса студентов 1 курса стоматологического факультета УГМА. Терапевтическая стоматология. 2012;6:22-24.

19. Voytenko VP. The healthof healthy. Kiev: Zdorov'e, 1991. (In Russian)

Войтенко В.П. Здоровье здоровых. Киев: Здоровье, 1991.

\section{Інформація про авторів:}

\section{Савченко Валентин}

http://orcid.org/0000-0002-8483-9748

Київський університет імені Бориса Грінченка, Київ, Україна

v.savchenko@kubg.edu.ua

\section{Буряк Ольга}

https://orcid.org/0000-0001-7074-5743

Київський університет імені Бориса Грінченка, Київ, Україна o.buriak@kubg.edu.ua

\section{Комоцька Оксана}

http://orcid.org/0000-0003-3109-1120

Київський університет імені Бориса Грінченка, Київ, Україна o.komotska@kubg.edu.ua

\section{Погребняк Юлія}

https://orcid.org/0000-0002-7450-3562

Київський університет імені Бориса Грінченка, Київ, Україна y.pohrebniak@kubg.edu.ua

\section{Якимчук Олег}

https://orcid.org/0000-0002-8126-212X

Київський університет імені Бориса Грінченка, Київ, Україна

o.yakymchuk@kubg.edu

Отримано: 23.05.2019;

Прийнято 13.06.2019; Опубліковано: 28.06.2019. 